\title{
補強コンクリートロツク造壁体で充填された 軽量鉄骨耐力壁の実験研究
}

正会員 伴 潔* 同 $\bigcirc$ 竹山和彦** 同 米本佳弘***

本報告は、前報告1) 亿引続いて実施した、補強コンク リートブロック造壁体で充填された軽量鉄骨耐力壁の形 状・寸法の異なる 3 種類の試験体（壁高一定で、壁長が 夫々壁高の $1 / 3,2 / 3,1 / 1$ ) についての面内水平方向交番 加力実験の結果隹関するものである。

1. 試験体 寸法 $390 \times 100 \times 190$ の空胴ブロック12段 積み 2 列、 4 列、 6 列の 3 種類の壁体を $2 \mathrm{C}-100 \cdot 50 \cdot 20$ 3.2 の柱・梁化 PL- $200 \times 100 \times 3.22$ 枚を両面加ら当て $>$ 全周隅肉溶接で接合した枠架構の中へ後積みした。壁 体補強筋は、縦・横とも $9 \phi$ とし、夫々 $40 \mathrm{~cm}, 60 \mathrm{~cm}$ 間隔に捅入して、2 重ナットで枠架構に碇着した。壁高 は $251 \mathrm{~cm}$ 壁長は夫々 $91 \mathrm{~cm}, 171 \mathrm{~cm}, 251 \mathrm{~cm}$ である。

2. 実験結果 (a)周辺目地汇初亀裂力溌生するのは 層暁みが約 $h / 3,000(h$ : 壁高) に達した時であり、層 暁みが $h / 800 \sim h / 500$ に達するとブロックに亀裂が入り 始め、ブロックの破片が落下し始めるのは、減力時であ つて明確ではないが、凮暁みが $h / 80 \sim h / 50$ 程度に達し た時と推定される。

（b）枠架構注柱頭のガゼットプレートが、亀裂の入 つた壁体の突き上げにより、亀裂が入つたり切断したり

第 1 表 白 裂、荷 重

\begin{tabular}{|c|c|c|c|c|c|c|c|c|}
\hline \multirow{3}{*}{\multicolumn{2}{|c|}{$\begin{array}{l}\text { 試 験 体 } \\
\text { 記号 - 番号 }\end{array}$}} & \multirow{3}{*}{\begin{tabular}{|c|} 
目 \\
地 \\
材 \\
令 \\
(日)
\end{tabular}} & \multirow{2}{*}{\multicolumn{2}{|c|}{$\begin{array}{l}\text { 䓟辺目地 } \\
\text { 初鲁裂全周魚裂 }\end{array}$}} & \multirow{3}{*}{ 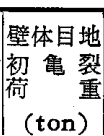 } & \multirow{3}{*}{\begin{tabular}{l}
\multicolumn{2}{c}{7} \\
初亀裂 \\
荷 重 \\
(ton)
\end{tabular}} & \multirow{3}{*}{ 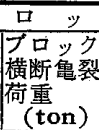 } & \multirow{3}{*}{ 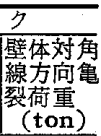 } \\
\hline & & & & & & & & \\
\hline & & & $\begin{array}{l}\text { 荷 重 } \\
\text { (ton) }\end{array}$ & $\begin{array}{l}\text { 荷 重 } \\
\text { (ton) }\end{array}$ & & & & \\
\hline \multirow{2}{*}{$1 / 3$} & No.1 & 28 & $\begin{array}{r}1.0 \\
-2.0 \\
\end{array}$ & $\begin{array}{r}8.0 \\
-8.0 \\
\end{array}$ & $\begin{array}{r}6.0 \\
-5.0 \\
\end{array}$ & $\begin{array}{r}5.0 \\
-5.0 \\
\end{array}$ & $\begin{array}{r}8.0 \\
-8.5 \\
\end{array}$ & $\begin{array}{r}9.0 \\
-8.5 \\
\end{array}$ \\
\hline & No.2 & 26 & $\begin{array}{r}4.0 \\
-6.0 \\
\end{array}$ & $\begin{array}{r}6.0 \\
-8.4 \\
\end{array}$ & $\begin{array}{r}6.0 \\
-6.0 \\
\end{array}$ & $\begin{array}{r}6.0 \\
-6.0 \\
\end{array}$ & $\begin{array}{r}8.0 \\
-8.0 \\
\end{array}$ & $\begin{array}{r}9.7 \\
-8.0\end{array}$ \\
\hline \multirow{2}{*}{$2 / 3$} & No.1 & 14 & $\begin{array}{r}8.0 \\
-2.0 \\
\end{array}$ & $\begin{array}{r}14.0 \\
-8.0 \\
\end{array}$ & $\begin{array}{r}4.0 \\
-2.0 \\
\end{array}$ & $\begin{array}{r}4.0 \\
-2.0 \\
\end{array}$ & $\begin{array}{r}12.0 \\
-13.0 \\
\end{array}$ & $\begin{array}{r}22.0 \\
-13.0 \\
\end{array}$ \\
\hline & No. 2 & 21 & $\begin{array}{r}8.0 \\
-8.0 \\
\end{array}$ & $\begin{array}{r}12.0 \\
-12.0 \\
\end{array}$ & $\begin{array}{r}8.0 \\
-8.0 \\
\end{array}$ & $\begin{array}{r}8.0 \\
-8.0 \\
\end{array}$ & $\begin{array}{r}10.5 \\
-10.0 \\
\end{array}$ & $\begin{array}{r}12.0 \\
-12.0 \\
\end{array}$ \\
\hline \multirow{2}{*}{$1 / 1$} & No.1 & 20 & $\begin{array}{r}6.0 \\
-6.0 \\
\end{array}$ & $\begin{array}{r}21.0 \\
-21.0 \\
\end{array}$ & $\begin{array}{r}12.0 \\
-12.0 \\
\end{array}$ & $\begin{array}{r}12.0 \\
-14.0 \\
\end{array}$ & $\begin{array}{r}17.0 \\
-14.0 \\
\end{array}$ & $\begin{array}{r}20.0 \\
-24.0 \\
\end{array}$ \\
\hline & No.2 & 21 & $\begin{array}{r}8.0 \\
-8.0\end{array}$ & $\begin{array}{r}18.0 \\
-18.0\end{array}$ & $\begin{array}{l}12.0 \\
12.0\end{array}$ & $\begin{array}{r}17.0 \\
-12.0 \\
\end{array}$ & $\begin{array}{r}17.0 \\
-17.0 \\
\end{array}$ & $\begin{array}{r}26.0 \\
-19.5 \\
\end{array}$ \\
\hline
\end{tabular}

Uた。

（c）第 2 表に示す如く、最大荷重時の壁体平均剪断 応力度は、ブロック単体圧縮強さの約 $1 / 15$ に相当する。

（d）最大荷重に達した後の、壁体に亀裂が入つた状 態になつてもまだ相当な荷重を支える能力を有している

（e）初期汇於ける層暁み量は、鉄筋コンクリート複 筋梁の如く、引張側壁体断面を無効と仮定した計算值に 一致。

（f）ブロックに刍裂が発生する直前の剛性は周辺目 地初龟裂発生時の剛性の 60\%～80\% 亿低下する。

(g) 、枠架構柱軸方向力は、層暁み計算と同じ仮定に よる計算值に一致する。梁には殆んど軸方向は生じない。

3. この耐力壁は、剛性・靯性に於いて、軸組筋違と 同等であり、短期荷重時に於いて、壁体目地に重裂が発 生しない様、適当な安全率を用いれば、充分実用に供し 得るものと思われる。（記）本実験は日本軽量鉄骨建築 協会の研究費によるものである。

1）筆者: 耐水平力要素をもつ軽量鉄骨単一架構の実験研究。 学論報 66 号 $529 / 532$ 昭 35.10

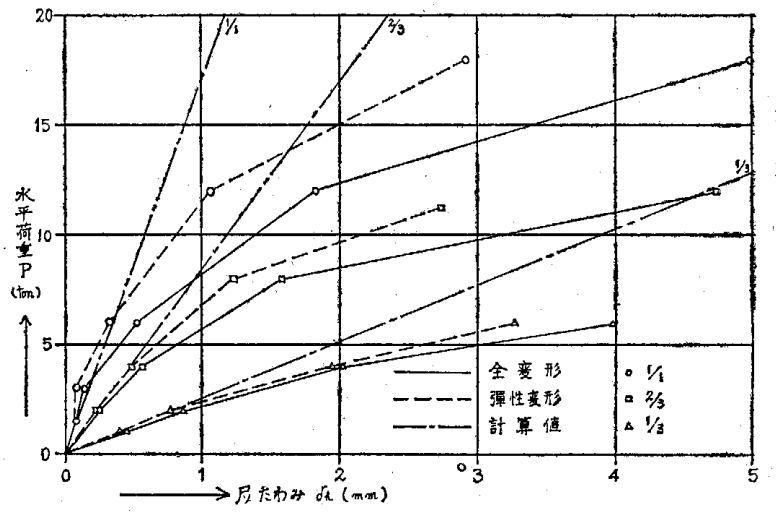

第 1 図 交番荷重と層たわみの関係

第 2 表 最 大 荷 重

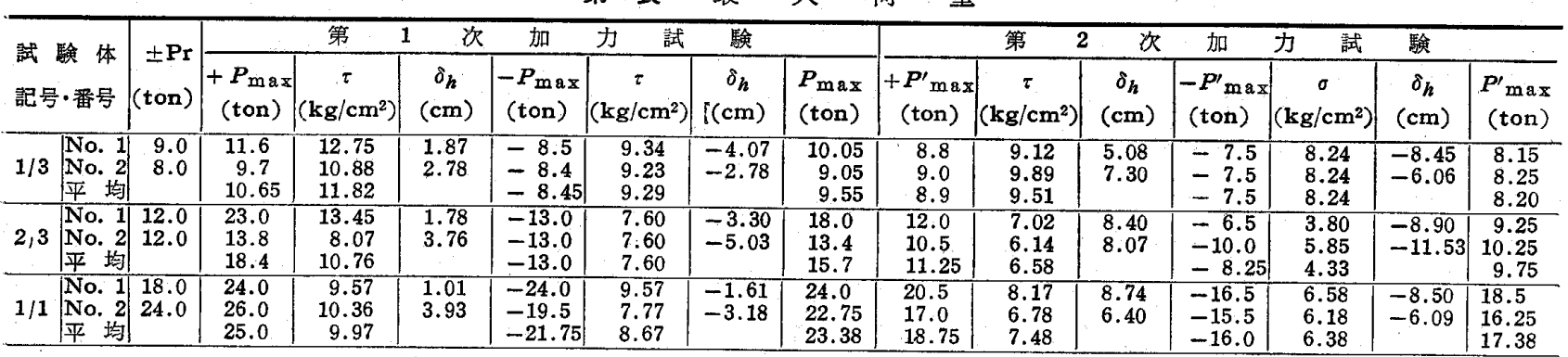

$\pm \mathrm{Pr}$ : 最大耐力確認前に於ける交番最大荷重

$+P_{\max },-P_{\max }, P_{\max }$ : 第 1 次加力試験に於ける正・負最大荷重㧍よびをの平均値. ( $\boldsymbol{P}^{\prime}$ は第 2 次加力試験に依え值)

$\tau:$ 平均剪断応力度。(荷重 $/$ 壁体全断面皘)。 $\delta_{h}$ : 層暁み

* 神戸大学教授 工博 $* * *$ 神戸大学助手

*** 住友金属工業 K.K. 製品開発部 